\title{
Effects of Milk Production Capacity and Metabolic Status on HPA Function in Early Postpartum Dairy Cows
}

\author{
B. Beerda, ${ }^{1}$ J. E. Kornalijnslijper, ${ }^{2}$ J. T. N. van der Werf, ${ }^{1}$ \\ E. N. Noordhuizen-Stassen, ${ }^{2}$ and H. Hopster ${ }^{1}$ \\ ${ }^{1}$ Animal Sciences Group of Wageningen UR, Division Animal Resources Development, \\ Research Group Animal Welfare, 8200 AB Lelystad, The Netherlands \\ ${ }^{2}$ Department of Farm Animal Health, Ruminant Health Unit, Faculty of Veterinary Medicine, \\ Utrecht University, 3584 CL Utrecht, The Netherlands
}

\begin{abstract}
Increasing milk yields in modern dairy cows cause concern that high yield may impair the cows' health and welfare, for example, via negative effects on metabolic status and hypothalamo-pituitary-adrenocortical (HPA) function. This study aims to investigate whether a high level of milk production, and the associated metabolic status, affects HPA function in dairy cows and changes their adaptive capacity. Additionally, it aims to establish whether possible effects of milk production level only show under challenging conditions. HolsteinFriesian cows, which produced on average 11,443 and $7727 \mathrm{~kg}$ of fat and protein-corrected milk (FPCM)/305 $\mathrm{d}$ in their previous lactation, were compared. During the dry period, the cows were fed to requirements or overfed. High milk yield and the concomitant large energy deficit were associated with 1) increased pituitary (re)activity, i.e., increased ACTH baseline concentrations and higher ACTH concentrations after corticotropin-releasing hormone (CRH) administration, and 2) decreased adrenocortical reactivity, i.e., lower cortisol responses after ACTH administration. Although significant, the effects of milk production level on HPA function were relatively small. Animals showed seemingly normal hormonal responses to $\mathrm{CRH}$ and $\mathrm{ACTH}$ administration. Also, cortisol baseline concentrations were unaffected. It seems, therefore, unlikely that the adaptive capacity of the high-producing cows was significantly impaired compared with their low-producing herdmates.
\end{abstract}

(Key words: milk production, metabolism, hypothalamo-pituitary-adrenocortical function, adaptive capacity)

Abbreviation key: $\mathbf{c}=$ control, $\mathbf{C R H}=$ corticotropinreleasing hormone, $\mathbf{E B}$ = energy balance(s), FPCM =

Received October 20, 2003.

Accepted February 24, 2004.

Corresponding author: B. Beerda; e-mail: bonne.beerda@wur.nl. fat- and protein-corrected milk, HP = high producing, HPA = hypothalamo-pituitary-adrenocortical, $\mathbf{L P}=$ low producing, $\mathbf{n A U R C}=$ net area under the response curve, $\mathbf{N E B}=$ negative energy balance(s), $\mathbf{o}=$ overfed.

\section{INTRODUCTION}

Milk yield in modern dairy cows has increased considerably over the last decades, and there is evidence that this is accompanied by negative effects on the health and welfare of the animals (Pryce et al., 1998; Sinclair et al., 1999). Increases in energy output, i.e., milk production, are not matched by similar increases in energy input, i.e., food intake (Veerkamp et al., 1995), and the negative energy balance (NEB) that occurs in dairy cows in early lactation (Tamminga et al., 1997) increases with yield. This shows as a negative correlation between milk production level and postpartum energy balance (Benning et al., 2000). A large energy deficit in postpartum dairy cows may lead to metabolic disorders and increased risks of, for example, lameness or mastitis (for a discussion see Knight, 2001). The metabolic system is closely connected with the hypothalamo-pituitary-adrenocortical (HPA) axis (Chrousos, 2000), a neuroendocrine system that orchestrates responses of the body to many different types of challenges. The HPA axis effectuates allostasis, i.e., stability through change (for a discussion on allostatic systems see McEwen, 2002), and its normal functioning is important for successful adaptation. The objectives of the present study are to investigate whether milk production level affects HPA function and whether possible effects of milk production level manifest themselves only under challenging conditions, e.g., suboptimal management.

\section{MATERIALS AND METHODS}

\section{Experimental Factors and Animals}

The experimental design, treatments, and procedures have been described in detail by Kornalijnslijper 


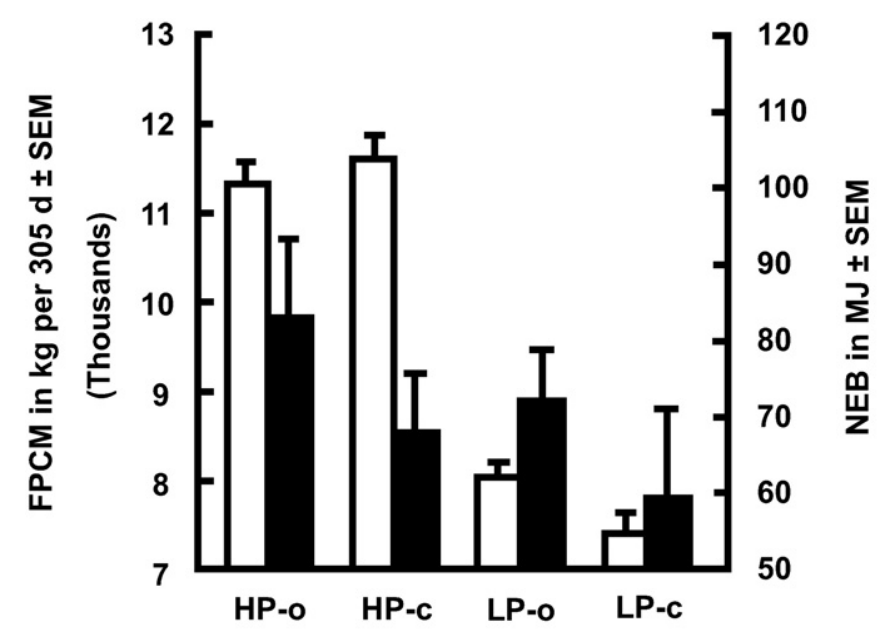

Figure 1. Mean milk production in the previous lactation (open bars and left y-axis) and mean calculated negative energy balance (NEB) during the first $9 \mathrm{~d}$ postpartum (filled bars and right y-axis). The cows were classified as high- (HP) or low- (LP) producing cows, on the basis of their previous lactation, and during the dry period fed according to requirements (-c) or overfed (-o). The means were based on 9 animals per group $(n=9)$, except for the LP-o group $(n=$ $10)$ and, with regard to NEB, the LP-c group $(n=7)$. FPCM = Fatand protein-corrected milk.

et al. (2003), and in the following section these are described briefly. The experiment consisted of a $2 \times 2$ factorial arrangement with production levels (high or low) and feeding regimens during the dry period (control and overfeeding) as experimental factors. Thirtynine cows, comprising 27 second-parity and 12 thirdparity animals, entered the study. The cows were $100 \%$ Holstein Friesian, except for 3 crossbreds ( $\geq 50 \%$ Holstein Friesian), and selected from the research farm's herd of about 400 cows. The 3 selection criteria were production level, i.e., relatively high or low, parity, i.e., second or third, and calving date, i.e., in and around the winter season of 2000/2001. Animals were selected according to their 305-d fat- and protein-corrected milk (FPCM) production in the previous lactation. There was a 'high-producing (HP) group' and a 'low-producing (LP) group' with mean FPCM of 11,443 $\pm 198 \mathrm{~kg}$ (ranging from 9999 to $13,364 \mathrm{~kg}$ ) and $7727 \pm 147 \mathrm{~kg}$ (ranging from 6596 to $8686 \mathrm{~kg}$ ), respectively (see Figure 1). The production groups were not completely balanced for parity, but each combination of production level and parity did include at least 7 animals. The cows were housed in a cubicle barn during the dry period and moved to a calving pen shortly before the expected calving date. After calving, the cows were housed in a tie stall. During the dry period, the cows were either fed according to recommendations for energy requirements (around $60 \mathrm{MJ} / \mathrm{d}$, control $=\mathbf{c}$ ) or fed about twice that amount (around $120 \mathrm{MJ} / \mathrm{d}$, overfed $=\mathbf{o}$ ), which is as- sumed to aggravate postpartum energy balance (Rukkwamsuk et al., 1999). The feeding treatments were assigned to the cows in a random way. The TMR was provided on a group basis. From the 10th day prior to expected calving, all animals were provided around 120 $\mathrm{MJ} / \mathrm{d}$. In the tie-stall, i.e., postpartum, the cows were fed TMR ad libitum, and their individual feed intakes were recorded. For more details on the rations, see Kornalijnslijper et al. (2003). Cows were milked twice a day at 6 a.m. and 4 p.m. The study was carried out between October 2000 and April 2001. The experiment was approved by the Institutes Animal Care and Ethics Committee.

\section{Measurements}

Milk production was recorded twice daily. Milk fat and protein percentages were measured in composite milk samplings from 4 successive milkings per week. Starting from 3 wk before their expected calving dates, the cows were sampled for blood twice a week, normally on Mondays and Thursdays around 11:30 a.m. Blood was collected from the tail vein and analyzed for glucose, NEFA, BHBA, urea, ACTH, and cortisol.

On Mondays, between 9 and $22 \mathrm{~d}$ postpartum, a catheter (Intraflon 2, Vygon, Ecouen, France) was inserted in the jugular vein of the cow. The next day, $10-\mathrm{mL}$ blood samples were taken every half hour between 8 a.m. and 2 p.m. The blood was collected by means of connecting prechilled EDTA-coated tubes (Vacuette, Greiner, The Netherlands) to a tap on the catheter, and immediately stored on ice. Within $1 \mathrm{~h}$ after collection, blood samples were centrifuged for $10 \mathrm{~min}$ at $1600 \times \mathrm{g}$ and $4^{\circ} \mathrm{C}$. Plasma was stored at -80 and $-20^{\circ} \mathrm{C}$ until analysis for ACTH and cortisol, respectively. On Wednesdays, a corticotropin-releasing hormone (CRH) stimulation test was performed. Blood samples of 10 $\mathrm{mL}$ were taken at $-15,0,15,30,45,60,90$, and 120 min following a bolus administration of $0.1 \mu \mathrm{g}$ of bCRH (Bachem, Switzerland)/kg BW at 12 noon. Finally, on Fridays, an ACTH stimulation test was performed. Blood samples of $10 \mathrm{~mL}$ were taken at $-15,0,15,30$, $60,90,120,180$, and 240 min following a bolus administration of 2 IU of ACTH (Synacthen, Novartis Pharma)/ $\mathrm{kg} \mathrm{BW}{ }^{0.75}$ at 10 a.m. All blood samples were handled and processed as described. Prior to the tests, starting after calving, the cows were habituated to the sampling procedures.

\section{Assays}

Commercially available kits were used to determine plasma glucose (Hexokinase method; Gluco-quant; Roche Diagnostics GmbH, Mannheim, Germany), 
NEFA (acyl-coenzyme A synthetase-acyl-coenzyme A oxidase enzymatic colometric method; Wako NEFA C test, Wako Chemicals USA Inc., Richmond, VA), BHBA (Hydroxybutyrate-dehydrogenase method; Roche Diagnostics $\mathrm{GmbH}$ ) and urea (glutamate dehydrogenase method; UR225, Randox Laboratories Ltd., Crumlin, UK).

A commercial ACTH assay for human plasma (Nichols Institute Diagnostics, San Juan Capistrano, CA) was validated for bovine plasma and used according to the instructions of the manufacturer. Extended time intervals between thawing of the samples and start of the assay, but not extended assay incubation, reduced ACTH concentrations. Therefore, the samples were thawed in series of 30 , placed on ice and pipetted within $45 \mathrm{~min}$, followed by the immediate start of the assay. Generally, assay incubation time varied between 20 and $24 \mathrm{~h}$, with maximal differences of $1 \mathrm{~h}$ for series within one assay. Standards and samples $(200 \mu \mathrm{L})$ were analyzed in duplicate. The radioactivity of the tubes was measured for $1 \mathrm{~min}$ in a model 1470 Wizard gamma counter, and the data were evaluated using Multicalc software (Wallac Oy, Finland). Preparatory to the study, different aspects of the ACTH assay were investigated. Bovine plasma samples low in ACTH, high in $\mathrm{ACTH}$, and a 50/50\% mixture of these, were analyzed in 7 different assays to check for linearity and reproducibility. Mean concentrations were 11.3, 81.6, and 45.4 $\mathrm{pg} / \mathrm{mL}$ and interassay coefficients of variation were 8.7, 3.9 , and $3.4 \%$, respectively. Intraassay CV $(\mathrm{n}=14)$ of the mixture was $2.6 \%$. The recovery of $2.6,7.75,26.25$, and $77.5 \mathrm{pg}$ of ACTH ( $50 \mu \mathrm{L}$ of assay standards $\mathrm{E}$ to $\mathrm{H}$ containing about 50, 150, 500, and $1500 \mathrm{pg} / \mathrm{mL}$ ) added to $150 \mu \mathrm{L}$ of the ACTH low sample was $98,93,95$, and $86 \%$, respectively. Detection limit, based on the positive $95 \%$ confidence limit $(\mathrm{n}=16)$ of the zero standard, was $1 \mathrm{pg} / \mathrm{mL}$. Values below the detection limit were set on the detection limit.

Cortisol was measured using a time resolved fluoroimmunoassay in unextracted bovine EDTA plasma (Erkens et al., 1998). Similar to the ACTH assay, aspects of the cortisol assay were investigated prior to the study. The intraassay CV for control samples with mean concentrations of $10.3,71.1$, and $39.2 \mathrm{ng} / \mathrm{mL}$ were $11.3,8.2$, and $7.9 \%(\mathrm{n}=16)$. The corresponding interassay CV were $12.8,10.6$, and $6.5 \%(\mathrm{n}=21)$. The detection limit of the cortisol assay was $0.5 \mathrm{ng} / \mathrm{mL}$.

\section{Statistical Analyses}

From the measurements of HPA function, 8 summary variables were derived: mean ACTH and cortisol concentrations during the first $9 \mathrm{~d}$ postpartum, mean ACTH and cortisol concentrations as assessed by multi- ple blood sampling on a day about 2 to 3 wk postpartum, $\mathrm{CRH}$-induced ACTH and cortisol responses (expressed as net area under the response curve: nAURC), ratios of $\mathrm{CRH}$-induced ACTH responses to $\mathrm{CRH}$-induced cortisol responses, and ACTH-induced cortisol responses (expressed as nAURC). Six summary variables linked to metabolism were considered: milk production level in the previous lactation, mean calculated energy balance (EB) during the first $9 \mathrm{~d}$ postpartum, and mean blood concentrations during the first $9 \mathrm{~d}$ postpartum of glucose, NEFA, BHBA, and urea.

The results were analyzed by analysis of variance. The main effects production group (HP vs. LP), feeding regimen during the dry period (c vs. o) and parity (second or third), plus interactions for these 3 experimental factors were introduced into the model. Parity and interactions between the factors were omitted from final analyses when nonsignificant $(P>0.05)$. In addition to overall $F$-tests, means were compared pairwise by Student's $t$-test (Fisher's least significant difference method). Differences between metabolite levels prepartum (expressed as mean values during the $14 \mathrm{~d}$ before calving) and postpartum (expressed as mean values during the first $9 \mathrm{~d}$ postpartum) were tested by the paired $t$-test. Spearman correlations were calculated between the 14 summary variables, although the correlations between the 8 summary variables of HPA function are not presented, with observations having been corrected for the experimental factors production group and feeding regimen. The level of significance was maintained at an error rate $<0.05$, and this implies that some of the significant correlations may have been accidental. Calculations were performed with the statistical programming language GenStat (GenStat, 2000).

\section{RESULTS}

For reasons of poor udder health, 2 cows were excluded from the study. Another animal was treated with antibiotics for acute claw disorders at the time of the $\mathrm{CRH}$ and ACTH challenges and was, therefore, excluded from these tests. Because of practical problems there were missing observations for 2 cows for the ACTH challenges and energy balance for the first 9 d postpartum.

\section{Energy Balance and Metabolite Concentrations}

The calculated EB and plasma metabolite concentrations until 3 wk postpartum have been reported elsewhere (Kornalijnslijper et al., 2003). Here, the results until $9 \mathrm{~d}$ postpartum are summarized (see Figures 1 and 2) as these data were used to calculate correlations 

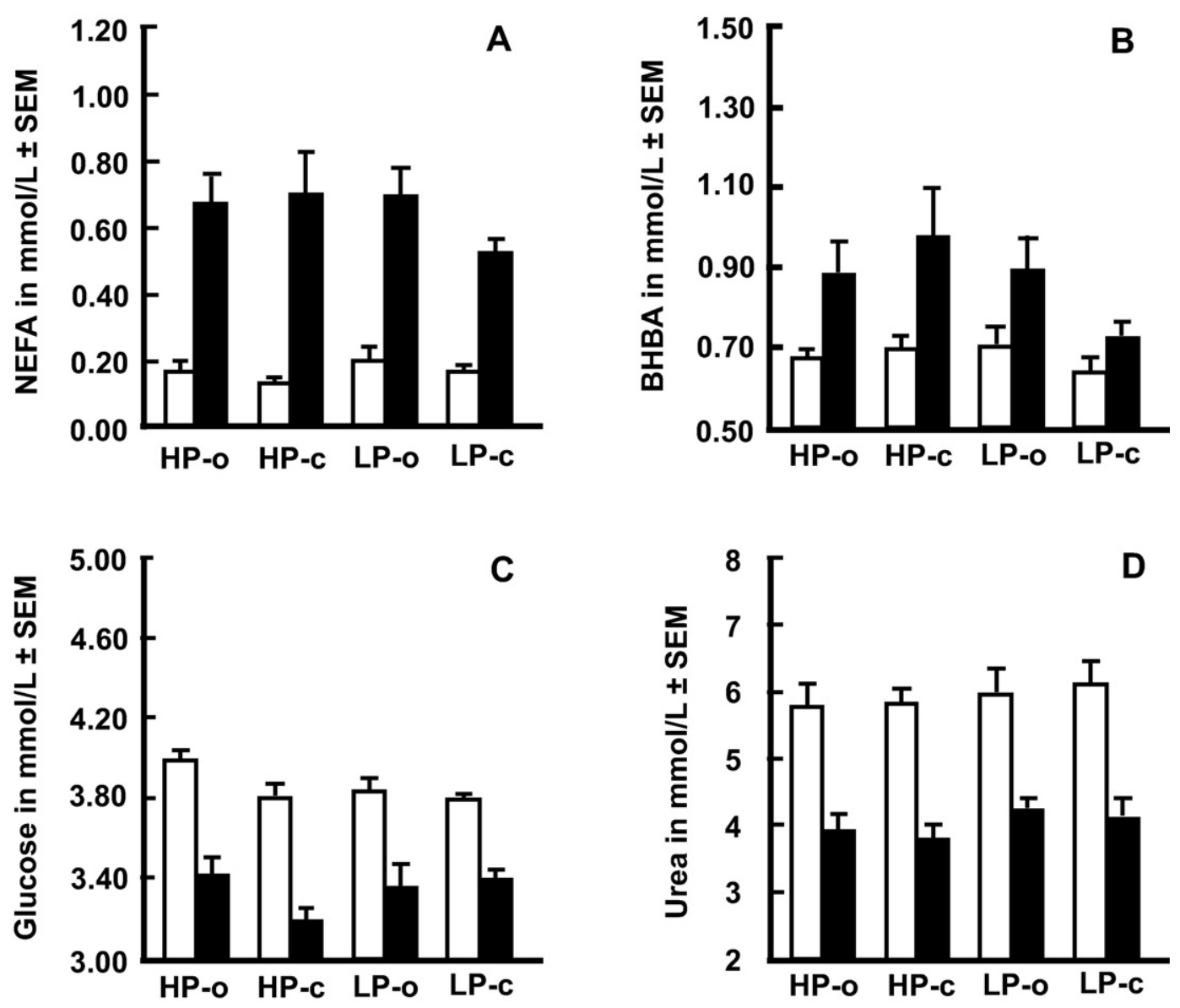

Figure 2. Mean plasma NEFA (A), BHBA (B), glucose (C), and urea (D) concentrations during the last 2 wk prepartum (open bars) and the first $9 \mathrm{~d}$ postpartum (filled bars). The cows were classified as high- (HP) or low- (LP) producing cows, on the basis of their previous lactation, and during the dry period fed according to requirements (-c) or overfed (-o). The means were based on 9 animals per group except for the LP-o group $(\mathrm{n}=10)$. Mean prepartum concentrations differed significantly $(P<0.001)$ from mean postpartum concentrations.

between metabolism and HPA function. In Figure 1, the calculated NEB for the first 9 d postpartum are presented together with the 305-d FPCM productions in the previous lactation. Postpartum, the cows had negative EB that was aggravated with high milk production and overfeeding (see Kornalijnslijper et al., 2003). Compared with prepartum concentrations, plasma NEFA and BHBA concentrations during the 9 $\mathrm{d}$ after calving were significantly $(P<0.001)$ increased, whereas postpartum plasma glucose and urea concentrations were significantly $(P<0.001)$ decreased. Metabolite concentrations were similar for the different groups (Figure 2A to D).

\section{ACTH and Cortisol Baseline Concentrations and Responses}

The mean plasma ACTH and cortisol concentrations in the period from 2 wk before until 3 wk after parturi- tion are presented in Figure 3A and B. The ACTH levels during the first $9 \mathrm{~d}$ after calving $(4.1 \pm 0.4 \mathrm{pg} / \mathrm{mL})$ were significantly $(P<0.001)$ higher than those during the 2 wk prior to calving $(2.6 \pm 0.2 \mathrm{pg} / \mathrm{mL})$. Postpartum, the cows that had been overfed during the dry period $(5.0 \pm 0.6 \mathrm{pg} / \mathrm{mL})$ had significantly $(P<0.05)$ higher ACTH levels than the cows that had been fed according to requirements $(3.3 \pm 0.4 \mathrm{pg} / \mathrm{mL})$. The ACTH levels were highest for the LP-o group $(5.5 \pm 0.9 \mathrm{pg} / \mathrm{mL})$, and these were significantly $(P<0.05)$ higher than those for the LP-c group $(2.6 \pm 0.4 \mathrm{pg} / \mathrm{mL})$. Mean values for the HP-o and HP-c groups were $4.4 \pm 0.5$ and $3.9 \pm 0.6$ $\mathrm{pg} / \mathrm{mL}$, respectively. Cortisol levels during the $2 \mathrm{wk}$ before parturition and first $9 \mathrm{~d}$ postpartum were on average $6.2 \pm 0.4$ and $6.0 \pm 0.4 \mathrm{ng} / \mathrm{mL}$, respectively. In line with the ACTH levels, LP-o cows $(7.4 \pm 1.0 \mathrm{ng} / \mathrm{mL})$ had significantly $(P<0.05)$ higher postpartum cortisol levels. This time compared to the HP-o cows (5.1 \pm 0.5 

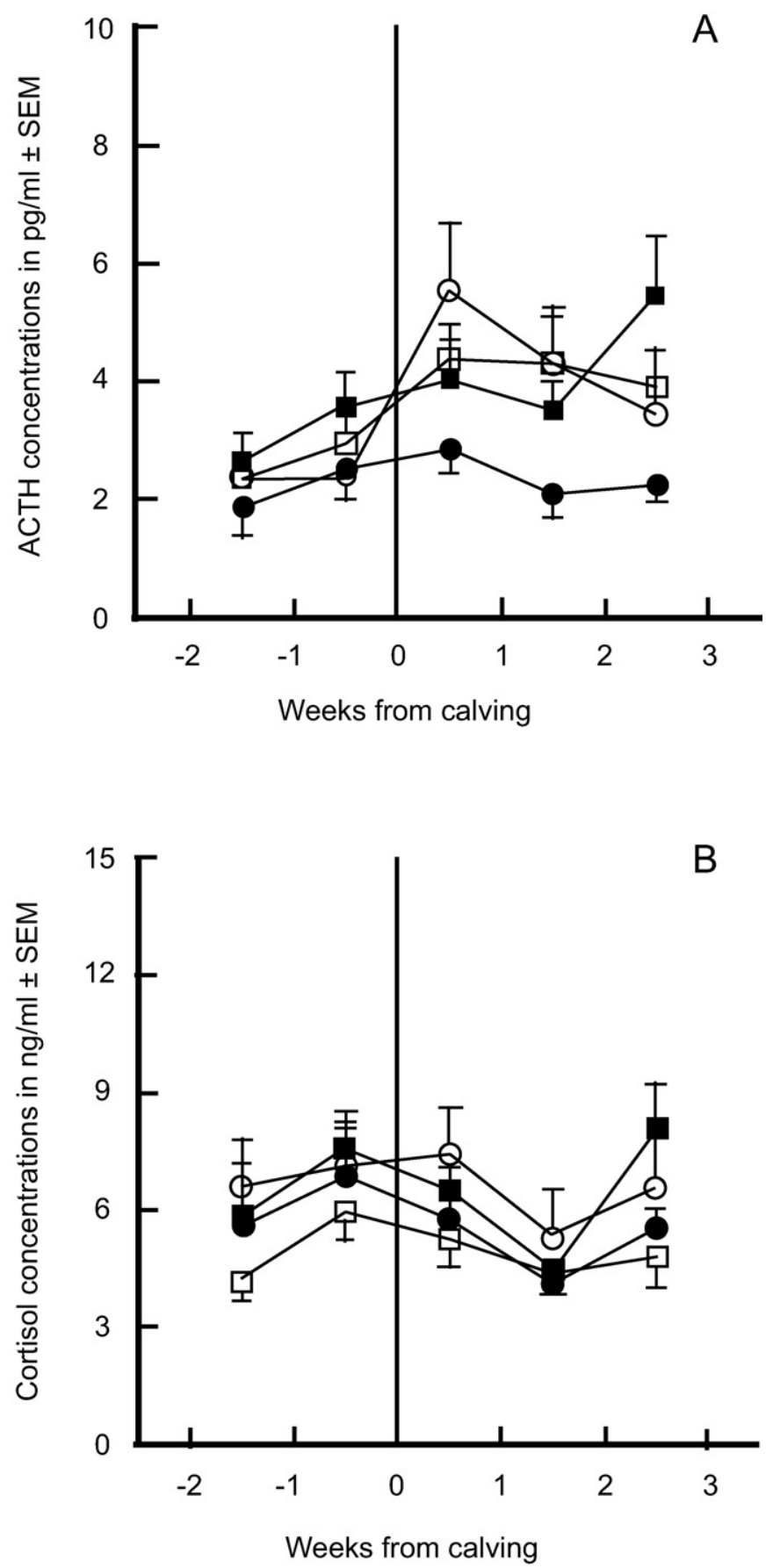

Figure 3. Mean plasma ACTH (A) and cortisol (B) concentrations in high (HP, square markers) and low (LP, round markers) yielding dairy cows. During the dry period the cows were fed according to requirements (-c, solid markers) or overfed (-o, open markers). Blood samples were taken twice per week. The means were based on 9 animals per group, except for the LP-o group $(n=10)$. Mean concentrations prepartum and postpartum differed significantly $(P<0.001)$ Overfed cows had higher $(P<0.05)$ postpartum ACTH concentrations than cows fed to requirements. Postpartum ACTH concentrations were higher $(P<0.05)$ in LP-o than in LP-c. Postpartum cortisol concentrations were higher $(P<0.05)$ in LP-o than in HP-o. $\mathrm{ng} / \mathrm{mL}$ ). The respective means for the HP-c and LP-c groups were $6.3 \pm 0.6$ and $5.2 \pm 0.6 \mathrm{ng} / \mathrm{mL}$.

The mean plasma ACTH and cortisol concentrations from 8 a.m. to 2 p.m., which were measured on a day between 11 and $24 \mathrm{~d}$ postpartum, are presented in Figure $4 \mathrm{~A}$ and $\mathrm{B}$. The mean ACTH baseline was $2.8 \pm 0.2$ $\mathrm{pg} / \mathrm{mL}$. For cortisol, this was $4.3 \pm 0.2 \mathrm{ng} / \mathrm{mL}$.

The $\mathrm{CRH}$-induced ACTH and cortisol responses are presented in Figure 5A and B. Mean ACTH responses expressed as peak value and nAURC were $79.7 \pm 6.9$ $\mathrm{pg} / \mathrm{mL}$ and $4051 \pm 370 \mathrm{~min} \times \mathrm{pg} / \mathrm{mL}$, respectively. The mean CRH-induced cortisol responses were $29.5 \pm 1.4$ $\mathrm{ng} / \mathrm{mL}$ (peak value) and $1571 \pm 119 \mathrm{~min} \times \mathrm{ng} / \mathrm{mL}$ (nAURC). Third-parity cows had significantly $(P<0.01)$ higher CRH-induced ACTH responses than second-parity cows, i.e., a mean nAURC of $5863 \pm 690$ compared with $3253 \pm 336 \mathrm{~min} \times \mathrm{pg} / \mathrm{mL}$. Subsequent $\mathrm{CRH}$-induced cortisol responses were also significantly $(P<0.05)$ higher in third-parity cows than in second-parity cows, with mean nAURC of $1974 \pm 277$ and $1393 \pm 107 \mathrm{~min}$ $\times \mathrm{pg} / \mathrm{mL}$, respectively. The CRH-induced ACTH and cortisol responses were independent of production level or feeding regimen.

Mean ratios of $\mathrm{CRH}$-induced $\mathrm{ACTH}$ response to $\mathrm{CRH}$ induced cortisol response are presented in Table 1. The ratios were significantly $(P<0.05)$ influenced by feeding regimen, interactions between feeding regimen and production level, and interactions between feeding regimen and parity. Ratios in the overfed animals, especially in HP-o cows, were higher than in the cows fed to requirements. The mean ratio for the HP-o group was significantly $(P<0.01)$ higher than the ratio for the HP-c group. The second-parity cows that were fed to requirements had a mean ratio of $1.9 \pm 0.1$, which was significantly $(P<0.05)$ lower than both the $3.4 \pm$ 0.1 of the overfed second-parity animals and the $3.4 \pm$ 0.3 of the third-parity cows fed to requirements. Thirdparity overfed cows had a mean ratio of $2.9 \pm 0.2$.

The mean ACTH-induced cortisol responses per group are presented in Figure 6. The overall mean peak value was $52.4 \pm 1.7 \mathrm{ng} / \mathrm{mL}$ and the mean $\mathrm{nAURC}$ curve was $7277 \pm 283 \mathrm{~min} \times \mathrm{ng} / \mathrm{mL}$. The HP cows had significantly $(P<0.05)$ lower ACTH-induced cortisol responses than LP cows. Mean values expressed as $n A U R C$ in min $\times \mathrm{ng} / \mathrm{mL}$ were $6605 \pm 312$ and $7874 \pm 414$, respectively.

\section{Correlations Between Summary Variables of Metabolism and HPA Function}

The cows' milk production levels in the previous lactation correlated negatively with their calculated EB for the first $9 \mathrm{~d}$ postpartum $(\mathrm{r}=-0.45, \mathrm{n}=35, P<0.01)$ and positively with mean NEFA concentrations during the first $9 \mathrm{~d}$ postpartum $(\mathrm{r}=0.40, \mathrm{n}=37, P<0.05)$. 

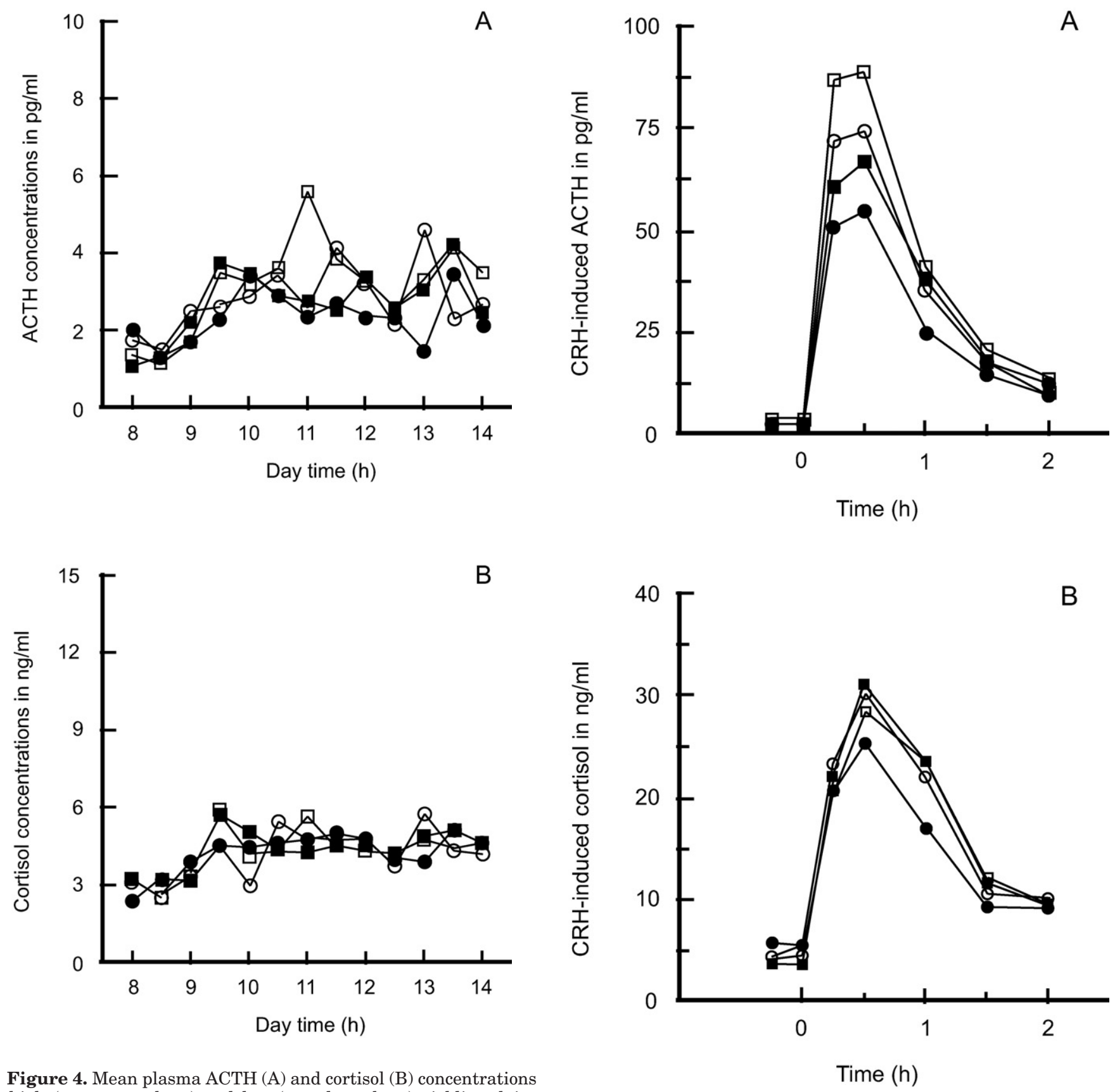

Figure 4. Mean plasma ACTH (A) and cortisol (B) concentrations in high (square markers) and low (round markers) yielding dairy cows. During the dry period the cows were fed according to requirements (solid markers) or overfed (open markers). Blood samples were taken every half hour from 8 a.m. to 2 p.m. on $1 \mathrm{~d}$ between 11 and $24 \mathrm{~d}$ postpartum. The means were based on 9 animals per group except for the low-producing overfed animals $(\mathrm{n}=10)$. ACTH and cortisol levels were similar for the different groups.

During the first $9 \mathrm{~d}$ postpartum, calculated EB correlated negatively with mean NEFA $(\mathrm{r}=-0.81, \mathrm{n}=35$, $P<0.001)$ and BHBA $(\mathrm{r}=-0.55, \mathrm{n}=35, P<0.001)$ concentrations. Mean NEFA concentrations were correlated positively with mean BHBA concentrations $(\mathrm{r}=$

Figure 5. Mean $(\mathrm{n}=9)$ corticotropin-releasing hormone $(\mathrm{CRH})$ $(0.1 \mu \mathrm{g} / \mathrm{kg} \mathrm{BW})$-induced plasma ACTH (A) and cortisol (B) responses in high (square markers) and low (round markers) yielding dairy cows. During the dry period the cows were fed according to requirements (solid markers) or overfed (open markers). ACTH and cortisol responses were similar for the different groups.

$0.56, \mathrm{n}=37, P<0.001)$, which on their turn correlated negatively with mean glucose concentrations $(\mathrm{r}=-0.45$, $\mathrm{n}=37, P<0.01$ ).

The significant correlations between summary variables of HPA function and metabolism are presented 
Table 1. Mean ( \pm SEM, $n=9$ ) ratios of corticotropin-releasing hormone $(0.1 \mu \mathrm{g} / \mathrm{kg}$ BW)-induced ACTH to cortisol responses (expressed as net area under the response curve). The cows were classified as high- (HP) or low- (LP) producing cows, on the basis of their previous lactation, and during the dry period fed according to requirements $(-c)$ or overfed (-o).

\begin{tabular}{llll}
\hline & -0 & $-c$ & Average \\
\hline HP & $3.7 \pm 0.6^{\mathrm{a}}$ & $2.1 \pm 0.3^{\mathrm{b}}$ & $2.9 \pm 0.4$ \\
LP & $2.7 \pm 0.4^{\mathrm{ab}}$ & $2.4 \pm 0.3^{\mathrm{ab}}$ & $2.5 \pm 0.2$ \\
Average & $3.2 \pm 0.4$ & $2.2 \pm 0.2^{1}$ & $2.7 \pm 0.2$ \\
\hline
\end{tabular}

${ }^{\mathrm{a}, \mathrm{b}, \mathrm{ab}}$ Differences between combinations of production level and feeding regimen are significant $(P<0.05)$ if superscripts have no letter in common. Ratios in overfed cows were significantly $(P<0.05)$ higher than ratios in cows fed according to requirements.

in Table 2. Relatively high production levels and severe calculated NEB were associated with high ACTH responses and baseline concentrations, but with low cortisol responses. Similar associations were found between plasma metabolite concentrations and HPA function, with low glucose and high NEFA mirroring severe NEB (see Table 2).

\section{DISCUSSION}

The metabolic system intertwines with the HPA axis (Chrousos, 2000; Sapolsky et al., 2000), a classic stressresponsive system that orchestrates adaptive responses, i.e., allostasis (see McEwen, 2002). Mediators of allostasis, such as glucocorticoids, effectuate adaptation, but as a 'side effect' can cause wear and tear, i.e., allostatic load. Abnormal HPA function could impair the adaptive capacity of dairy cows and make them vulnerable for disease and poor welfare. Here, it was investigated whether a high level of milk production affects HPA function in cows. The results associate a high milk production level and a concomitant severe NEB with 1) increased pituitary (re)activity, i.e., ACTH baseline concentrations and responses to $\mathrm{CRH}$, and 2) decreased adrenocortical reactivity, i.e., cortisol responses to ACTH. The effects of milk production level on HPA function were relatively small, and baseline cortisol levels were unaffected. It seems unlikely that the adaptive capacity of the HP cows in this study was significantly impaired compared with their LP herdmates. Relatively high milk production levels were associated with minor changes in HPA function, i.e., allostatic responses, but not with allostatic load. The present study may have underestimated the effects of high yield on HPA function under field conditions as, postpartum, the experimental cows had access to high quality food that was available to them continuously without having to compete for food with other animals. The study took place over several months, and seasonal effects may have influenced the physiological measure-

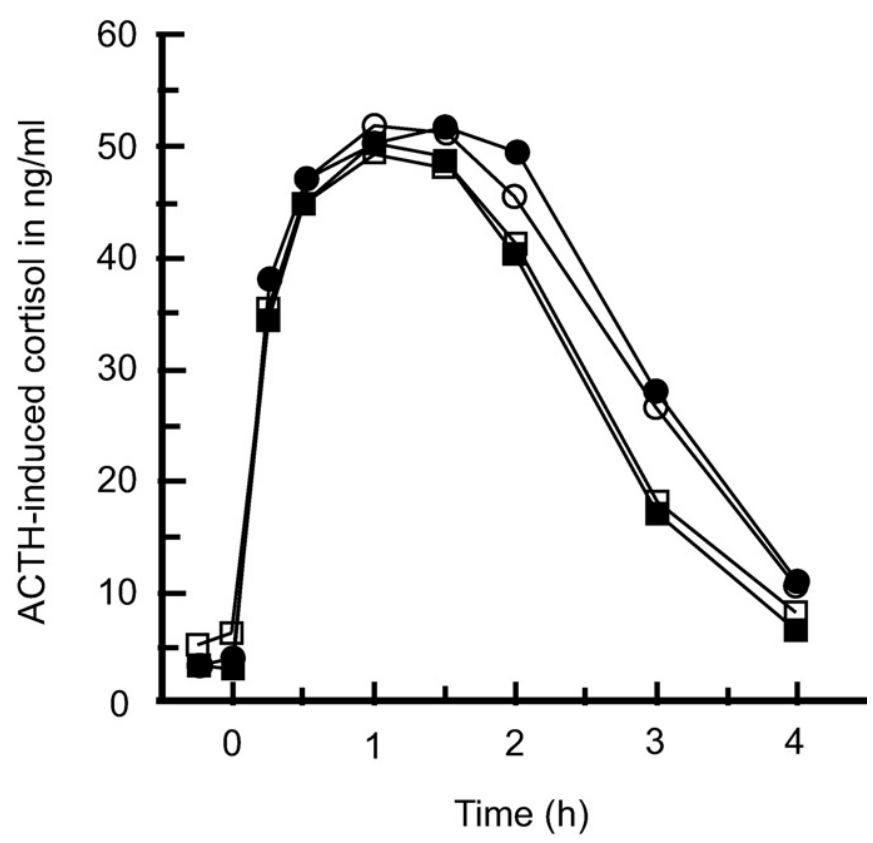

Figure 6. Mean ACTH (2 IU/kg BW ${ }^{0.75}$ )-induced plasma cortisol responses in high (square markers) and low (round markers) yielding dairy cows. During the dry period the cows were fed according to requirements (solid markers) or overfed (open markers). The means were based on 9 animals per group except for the high producing overfed animals $(\mathrm{n}=7)$. High-producing cows had lower $(P<0.05)$ cortisol responses than low producing cows.

ments. Such effects will have been similar for the different experimental groups and are not likely to have biased the conclusions.

Overfeeding during the dry period, apart from raising ACTH baseline concentrations, increased ratios of $\mathrm{CRH}$-induced ACTH responses to cortisol responses. Also, third-parity cows had increased CRH-induced ACTH and cortisol responses compared with secondparity cows and more pronounced signs of metabolic stress, i.e., low postpartum glucose concentrations and high liver triacylglycerol (see Kornalijnslijper et al., 2003). Factors that contribute to severe NEB, i.e., high milk production level, over feeding during the dry period and multiple lactations, are thus associated with increased pituitary (re)activity and decreased adrenocortical reactivity. The present study does not identify the mechanisms that underlie these changes and factors outside the HPA axis, like the clearance rate of hormones, could play a role.

\section{ACTH and Cortisol Baseline Concentrations}

Mean pre- and postpartum ACTH concentrations, as assessed by 2 blood samplings per week, were $2.6 \pm 1.2$ and $4.1 \pm 2.2 \mathrm{pg} / \mathrm{mL}$, respectively. Such baselines are somewhat lower than the 10 to $15 \mathrm{pg} / \mathrm{mL}$ in calves, but 
Table 2. Significant correlations between summary variables of hypothalamo-pituitary-adrenocortical activity and metabolism.

\begin{tabular}{|c|c|c|c|c|}
\hline & $\mathrm{FPCM}^{1}$ & $\mathrm{~EB}^{2}$ & Glucose $^{2}$ & $\mathrm{NEFA}^{2}$ \\
\hline ACTH baseline ${ }^{3}$ & $0.33(\mathrm{n}=37) P<0.05$ & $-0.34(\mathrm{n}=35) P<0.05$ & & \\
\hline CRH-induced ACTH responses ${ }^{4}$ & $0.39(\mathrm{n}=32) P<0.05$ & $-0.51(\mathrm{n}=34) P<0.01$ & $-0.39(\mathrm{n}=36) P<0.05$ & \\
\hline $\begin{array}{l}\text { Ratio CRH-induced ACTH } \\
\text { to cortisol responses }{ }^{4}\end{array}$ & & $-0.59(\mathrm{n}=34) P<0.001$ & $-0.42(\mathrm{n}=36) P<0.05$ & $0.48(\mathrm{n}=36) P<0.01$ \\
\hline ACTH-induced cortisol responses ${ }^{4}$ & & $0.35(\mathrm{n}=32) P<0.05$ & & $-0.43(\mathrm{n}=34) P<0.05$ \\
\hline
\end{tabular}

${ }^{1}$ Fat- and protein-corrected milk productions in the previous lactation.

${ }^{2}$ Mean calculated energy balance and plasma concentrations of glucose and NEFA during the first $9 \mathrm{~d}$ postpartum.

${ }^{3}$ Mean baseline ACTH concentrations between 8 a.m. and 2 p.m on a day about 2 to 3 wk postpartum.

${ }^{4}$ Responses expressed as net area under the response curve.

approximate the baselines of 5 to $10 \mathrm{pg} / \mathrm{mL}$ in the same animals 1 yr later (Redbo, 1998). Mean cortisol values reported in the literature are often less than $10 \mathrm{ng} / \mathrm{mL}$, and in recent studies often under $5 \mathrm{ng} / \mathrm{mL}$ (Lefcourt et al., 1993; Hopster et al., 1999). In the present study, pre- and postpartum cortisol concentrations were $6.2 \pm$ 2.7 and $6.0 \pm 2.3 \mathrm{ng} / \mathrm{mL}$, respectively. The mean concentrations of ACTH $(2.8 \pm 1.2 \mathrm{pg} / \mathrm{mL})$ and cortisol $(4.3 \pm 1.1$ $\mathrm{ng} / \mathrm{mL}$ ) in blood collected by jugular catheter, between 8 a.m. and 2 p.m., were somewhat lower than those that were measured during the first $9 \mathrm{~d}$ postpartum in blood samples taken by venipuncture. Factors that may have caused the relatively low levels are the time since calving, the sampling time during the day and the sampling method. Baseline ACTH concentrations, but not cortisol concentrations, were raised for weeks after parturition. This may be linked to severe NEB as overfeeding increased postpartum ACTH concentrations and LP cows that were fed to requirements did not show differences between prepartum and postpartum ACTH concentrations.

\section{ACTH and Cortisol Responses}

Little is known about CRH stimulation tests in adult cattle. In response to a $\mathrm{CRH}$ dose similar to the one used in the present study, i.e., $0.1 \mu \mathrm{g} / \mathrm{kg} \mathrm{BW}$, male Holstein calves showed a mean ACTH peak value of 99 $\mathrm{pg} / \mathrm{mL}$ and a mean cortisol peak value of $14 \mathrm{ng} / \mathrm{mL}$ (Veissier et al., 1999). The lactating dairy cows in the present study showed mean CRH-induced ACTH and cortisol peak values of $79.7 \pm 41.6 \mathrm{pg} / \mathrm{mL}$ and $29.5 \pm 8.6$ $\mathrm{ng} / \mathrm{mL}$, respectively. It seems that the adrenocortices of cows are more sensitive to ACTH than those of calves (see also Redbo, 1998). There is ample information about ACTH-stimulation tests in cattle (Ladewig and Smidt, 1989; Verkerk et al., 1994). In adult cows, doses of $200 \mathrm{IU}$ of ACTH per animal or $1.98 \mathrm{IU} / \mathrm{kg}^{0.75}$, which amounts to $209 \mathrm{IU}$ for animals of $500 \mathrm{~kg}$, have been used most often. Studies with Friesian cows in midlactation reported mean ACTH (1.98 IU/kg BW ${ }^{0.75}$ )-induced corti- sol peak values between 40 to $48 \mathrm{ng} / \mathrm{mL}$ (Munksgaard and Simonsen, 1996), and this compares to the mean ACTH-induced cortisol peak value that we found, i.e. $52.4 \pm 9.8 \mathrm{ng} / \mathrm{mL}$.

\section{Relationships Between Indicators of Metabolism and HPA Function}

The mean EB during the first 9 d postpartum correlated negatively with the production level of the previous lactation, postpartum BHBA levels and, especially, postpartum NEFA levels. These findings are in line with expectation as high milk yield compromises EB (for discussions see Holtentius, 1989; Drackley et al., 1992; Veerkamp et al., 1995; Vernon and Pond, 1997; Rukkwamsuk et al., 1999; Benning et al., 2000). The milk production level and calculated EB in this study concerned 2 different lactations, and this might explain the relatively low correlation between them.

Correlations between summary variables of metabolism and HPA function associated severe NEB, which typically resulted from high yield, with increased pituitary (re)activity and decreased adrenocortical reactivity. Pituitary hyperresponsiveness, expressed as CRHinduced ACTH responses, was related significantly only to low glucose levels, whereas adrenocortical hyporesponsiveness, expressed as ACTH-induced cortisol responses, was related significantly only to high NEFA levels. Different pathways may mediate the effects of severe NEB on different levels of the HPA axis and at the pituitary level such pathways may be more strongly linked to glucose levels, whereas at the adrenocortical level pathways may be more linked to NEFA levels. A link between NEFA and cortisol makes sense intuitively, as NEFA may be metabolized to cholesterol and removal of the 6-carbon fragment from the side chain of cholesterol to form pregnenolone is the rate-limiting step in the steroid biosynthesis. A possible link between glucose and ACTH may be identified from studies with rats. Adrenalectomy increases central $\mathrm{CRH}$ activity, causing sympathetic outflow, ACTH secretion and re- 
duced food intake. Replacement with glucocorticoids normalizes these changes by suppressing CRH activity and, at least in rats, the same effect is accomplished via sucrose ingestion (Laugero et al., 2002).

The increases in pituitary (re)activity and decreases in adrenocortical reactivity that we associated with high milk production levels, overfeeding during the dry period and higher parity, i.e., factors that contributed to severe NEB, were relatively small in comparison with changes that have been related to, for example, stage of lactation. High- and low-producing cows showed normal HPA responses and maintained normal baseline concentrations of its end product, i.e., cortisol. Likely, the adaptive capacities of our high and low yielding animals were similar, and this interpretation is supported by their identical reactions to experimental intramammary Escherichia coli infection (Kornalijnslijper et al., 2003).

\section{ACKNOWLEDGMENTS}

The care taking of the cows by the staff of research farm 'Hoorn' (Lelystad) was highly appreciated. We are indebted to Bas Engel for his assistance with the statistical analysis. Joop Testerink assayed the blood samples for ACTH, cortisol, and metabolites, for which we are grateful. We thank Marieke van Baalen who helped in performing the experiments, and especially Marjan Bralten-Benning for preparing the study. This work was financially supported by the Netherlands Organization for Scientific Research (NWO), the Research Council for Earth and Life Sciences (ALW), and the Dutch Ministry of Agriculture, Nature and Food Quality.

\section{REFERENCES}

Benning, M. A., J. T. N. van der Werf, A. Klop, H. Hopster, and H. J. Blokhuis. 2000. Effects of milk production level and energy status on HPA-axis function in dairy cows. Pages $477-481$ in Proceedings of the Xth International Congress on Animal Hygiene, Maastricht, The Netherlands.

Chrousos, G. P. 2000. The role of stress and the hypothalamic-pituitary-adrenal axis in the pathogenesis of the metabolic syndrome: Neuro-endocrine and target tissue-related causes. Int. J. Obes. 24(Suppl. 2):S50-S55.

Dohoo, I. R., and S. Martin. 1984. Disease, production and culling in Holstein-Friesian cows. III. Disease and production as determinants of disease. Prev. Vet. Med. 2:671-690.

Drackley, J. K., M. J. Richard, D. C. Beitz, and J. W. Young. 1992. Metabolic changes in dairy cows with ketonemia in response to feed restriction and dietary 1,3-butanediol. J. Dairy Sci. 75:1622-1634.

Erkens, J. H. F., S. J. Dieleman, R. A. Dressendörfer, and C. J. Strasburger. 1998. A time-resolved fluoroimmunoassay for cortisol in unextracted bovine plasma with optimized procedures to eliminate steroid binding protein interference and to minimize non-specific streptavidin-europium binding. J. Steroid Biochem. Mol. Biol. 67:83-97.
GenStat 2000. The guide to Genstat. Release 4.2 VSN, Oxford, UK. Holtenius, P. 1989. Plasma lipids in normal cows around partus and in cows with metabolic disorders with or without fatty liver. Acta Vet. Scand. 30:441-445.

Hopster, H., J. T. N. van der Werf, J. H. Erkens, and H. J. Blokhuis. 1999. Effects of repeated jugular puncture on plasma cortisol concentrations in loose-housed dairy cows. J. Anim. Sci. 77:708-714.

Knight, C. H. 2001. Lactation and gestation in dairy cows: Flexibility avoids nutritional extremes. Proc. Nutr. Soc. 60:527-537.

Kornalijnslijper, J. E., B. Beerda, A. J. J. M. Daemen, J. T. N. van der Werf, T. Van Werven, T. A. Niewold, V. P. M. G. Rutten, and E. N. Noordhuizen-Stassen. 2003. The effect of milk production level on host resistance of dairy cows, as assessed by the severity of experimental Escherichia coli mastitis. Vet. Res. 34:721-736.

Ladewig, J., and D. Smidt. 1989. Behavior, episodic secretion of cortisol, and adrenocortical reactivity in bulls subjected to tethering. Horm. Behav. 23:344-360.

Laugero, K. D., F. Gomez, S. Manalo, and M. F. Dallman. 2002. Corticosterone infused intracerebroventricularly inhibits energy storage and stimulates the hypothalamo-pituitary axis in adrenalectomized rats drinking sucrose. Endocrinology 143:45524562.

Lefcourt, A. M., J. Bitman, S. Kahl, and D. L. Wood. 1993. Circadian and ultradian rhythms of peripheral cortisol concentrations in lactating dairy cows. J. Dairy Sci. 76:2607-2612.

McEwen, B. S. 2002. Sex, stress and the hippocampus: Allostasis, allostatic load and the aging process. Neurobiol. Aging 23:921939.

Munksgaard, L., and H. B. Simonsen. 1996. Behavioral and pituitary adrenal-axis responses of dairy cows to social isolation and deprivation of lying down. J. Anim. Sci. 74:769-778.

Pryce, J. E., R. J. Esslemont, R. Thompson, R. F. Veerkamp, M. A. Kossaibati, and G. Simm. 1998. Estimation of genetic parameters using health, fertility and production data from a management recording system for dairy cattle. Anim. Sci. 66:577-584.

Redbo, I. 1998. Relations between oral stereotypies, open-field behavior, and pituitary-adrenal system in growing dairy cattle. Physiol. Behav. 64:273-278.

Rukkwamsuk, T., T. A. M. Kruip, and T. Wensing. 1999. Relationship between overfeeding and overconditioning in the dry period and the problems of high producing dairy cows during postparturient period. Vet. Q. 21:71-77.

Sapolsky, R. M., L. M. Romero, and A. U. Munck. 2000. How do glucocorticoids influence stress responses? Integrating permissive, suppressive, stimulatory, and preparative actions. Endocrinol. Rev. 21:55-89.

Sinclair, M. C., B. L. Nielsen, J. D. Oldham, and H. W. Reid. 1999. Consequences for immune function of metabolic adaptations to load. Pages 113-118 in Metabolic Stress in Dairy Cows. J. D. Oldham, G. Simm, A. F. Groen, B. L. Nielsen, J. E. Pryce, and T. L. J. Lawrence, eds. Occasional Publication No. 24. Br. Soc. Anim. Sci.

Tamminga, S., P. A. Luteijn, and R. G. M. Meijer. 1997. Changes in composition and energy content of liveweight loss in dairy cows with time after parturition. Livest. Prod. Sci. 52:31-38.

Veerkamp, R. F., G. Simm, and J. D. Oldham. 1995. Genotype by environment interactions: Experience from Langhill. Pages 5965 in Breeding and Feeding the High Genetic Merit Dairy Cow. T. L. J. Lawrence, F. J. Gordon, and A. Carson, eds. Br. Soc. Anim. Sci. Occas. Publication no. 19.

Veissier, I., C. G. van Reenen, S. Andanson, and I. E. Leushuis. 1999. Adrenocorticotropic hormone and cortisol in calves after corticotropin releasing hormone. J. Anim. Sci. 77:2047-2053.

Verkerk, G. A., K. L. Macmillan, and L. M. McLeay. 1994. Adrenal cortex response to adrenocorticotropic hormone in dairy cattle. Domest. Anim. Endocrinol. 11:115-123.

Vernon, R. G., and C. M. Pond. 1997. Adaptations of maternal adipose tissue to lactation. J. Mammary Gland Biol. Neoplasia 2:231-241. 